All India Institute's staff is split over attempt to dismiss its director

An attempt by India's health minister to dismiss the director of the All India Institute of Medical Sciences in New Delhi has polarised its staff.

The minister, Anbumani Ramadoss, who is also the president of the institute, last week moved at a meeting of the institute's governing body to dismiss the director, Panangipalli Venugopal, a cardiothoracic surgeon.

The move triggered a two day strike by some students and teaching staff, who shut down the hospital. The media reported that two patients died after they were denied emergency care at the institute during the strike, although these are unconfirmed.

The strike was called off after the Delhi High Court, in response to a petition by Dr Venugopal, asked the government to explain its action and allowed the director to retain his position in the interim.

Dr Venugopal publicly criticised "a systematic undermining of the institute and the authority of the director."

The institute's governing body said the director was being dismissed because public officials are prohibited from publicly criticising government policy.

Ganapati Mudur New Delhi

\section{South Africa} blames deaths of 22 infants on the legacy of apartheid

South Africa's Department of Health has refused to hold anyone responsible for the deaths of 22 infants in KwaZulu-Natal after an outbreak of infection with Klebsiella bacteria in the neonatal nursery at the Mahatma Gandhi Memorial Hospital in Durban last year. It will also not be compensating parents who lost babies.

Instead it has blamed the system of apartheid, which ended in 1994, and past health systems for the failures-which its own scientific investigator said in a preliminary report were "mainly a microbiology/infection control issue."

A final report has not been released, and parents have decided to sue for compensation. A smaller group of parents whose babies died as a result of a power failure at a hospital in the Eastern Cape have also been told they will not be compensated, as it was not the health department's fault. They too are suing.

Almost all the parents concerned can only afford public health care and are largely black. Pat Sidley Johannesburg

\section{Poor leadership is blamed for financial problems in the NHS}

Inadequate leadership at board level or ineffective management-and on some occasions both-have led to the serious financial problems seen in some NHS bodies, says England's public spending watchdog.

Key people, including chief executives and finance directors, taking their "eye off the ball" and being distracted by other business, such as building projects, have led to "a lack of robust budget-setting" and poor accounting, says the Audit Commission in a report published this week.

For its report the commission reviewed 25 organisations that had been the subject of public interest reports in 2005 and 2006. Between them the organisations had a total deficit of $£ 174 \mathrm{~m}$ (€250m; \$320m) for the previous year.

Although some of the organisations were now "on the road to recovery," there were lessons to be learnt about the factors that led to their financial collapse, it said.

Among these were a high turnover of senior officials, a "reliance on short-term fixes," and a lack of engagement with clinicians.

Zosia Kmietowicz London

Learning the Lessons from Financial Failure in the NHS can be seen at www.audit-commission.gov.uk.

\section{Crime victims are given right to object to disclosure of their medical records to courts}

Clare Dyer legal correspondent, BMJ

A Crown Court judge acted unlawfully in ordering an NHS trust to hand over the psychiatric records of a 14 year old girl-without giving her a chance to objectto the man who was accused of sexually abusing her. This was a ruling by two senior judges at the High Court in London last week.

The ruling has widespread implications throughout the criminal justice system, particularly in rape cases. Judges often order doctors to disclose a crime victim's psychiatric records to the defendant's lawyers, who want to use them to undermine the plaintiff's credibility as a witness.

Lord Justice May and Mr Justice Forbes declared that the court breached the girl's right to privacy under the European Convention on Human Rights in ordering disclosure without giving her a say.

Saimo Chahal of Bindman and Partners, the firm of solicitors acting for the girl, who was named only as TB, said: "Her case has implications for all victims and third parties in criminal trials. The court must carry out a balancing exercise between their rights and those of the defendant."

Judge Paul Glenn, who ordered the disclosure at Stafford Crown Court on 28 November 2005, had been told that the defence case was that TB had a schoolgirl crush and had fantasised the abuse. The judge said that the defendant was a 34 year old man of good character and that his right to a fair trial out-

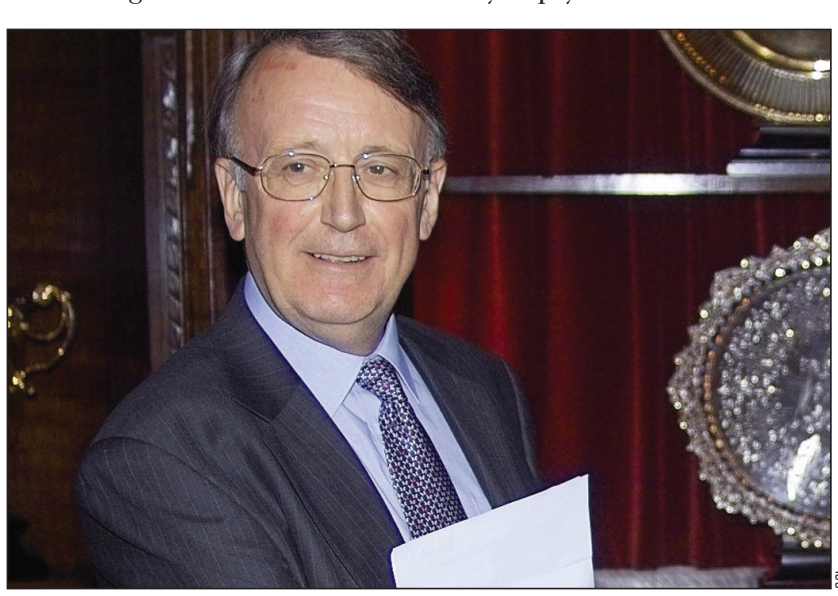

Lord Justice May said the Crown Court had been "invited to trample on [the girl's] rights of privacy and confidentiality." weighed confidentiality issues. He ordered disclosure of 23 pages of TB's psychiatric records, showing that she had a history of self harm and suicide attempts.

Two days later the court was told that the official solicitor was now representing TB in connection with a possible breach of her right to privacy.

On 5 December the judge, after holding two more hearings, called TB to court the next morning. The official solicitor was told only at $4 \mathrm{pm}$, and there was no time to arrange representation for TB.

She took time off school and came to court, where she consented reluctantly to disclosure after being told that otherwise the man's trial, in which she was the main prosecution witness, would be delayed. He was later convicted of sexual activity with a child.

Lord Justice May said he "strongly deprecated" what had happened to the girl, which was "quite unacceptable." The Crown Court had been "invited to trample on her rights of privacy and confidentiality."

Solicitor Jill Mason, representing the NHS trust, said: "This is a really important judgment for NHS trusts. The court has affirmed the importance of medical confidentiality and the right for a patient to be heard before medical notes are disclosed. This has been a concern for doctors for many years, especially in psychiatric matters." 